\title{
Dilemma-argumentation i radioprogrammet Mads og monopolet
}

\author{
Tidsskriftet Sakprosa \\ Bind 8, Nummer 2 \\ (C) 2016
}




\section{Sammendrag}

Denne artikel analyserer argumentationsdynamik, som den udspiller sig $i$ rammerne af et populært dansk radioprogram, Mads og Monopolet. Programmet modtager spørgsmål fra lytterne, spørgsmål, der har form som dilemmaer, som det tre mand store hold af kendisser skal rådgive ud fra. Dilemma-formen er et godt format til at synliggøre de ræsonnementer og argumenter, holddeltagerne verbaliserer. Programmets koncept, at give råd til den spørgende, gør at der er en drift hos deltagerne mod konsensus og samarbejde, som gør deltagerne lyttende og giver mulighed for at skifte mening undervejs. Dette står i skarp kontrast til politisk argumentation, hvor politikere ikke skifter holdning, men propaganderer for partiernes ideer. Denne dynamiske proces undersøges i detaljer. Da en udsendelse består af 8-1o dilemmaer, er det muligt at se på de enkelte deltageres evne til at få andre til at skifte standpunkt. Jeg benytter begrebet meningsattraktor til at undersøge dette, og finder at det er muligt operationalisere begrebet og vise forskellen $i$ holddeltagernes evne til at overbevise. Endvidere undersøges det, hvordan deltagerne bruger hinandens information og holdninger til at fiksere egne holdninger. De andre er en ressource, der kan bruges positivt til at frembringe det fælles produkt, som det endelige råd er.

Dilemmaargumentationen analyseres iforhold til debat og kritisk diskussion som argumentationsplatforme. Endelig vises det, at argumentationens dynamik kan analyseres i deltagernes vurdering af hinandens belæg.

\footnotetext{
Abstract

This article analyzes the argumentation dynamics as it played out in the framework of a popular Danish radio program, Mads and the Monopoly. The program receives questions from listeners. The questions have the shape of dilemmas that the three-man team of celebrities gives advise from. The dilemma form is a good format to highlight the dynamics of the reasoning
} 
and arguments, the team members verbalize. The program's concept, to give advice to the listeners, gives a drive among the participants toward consensus and cooperation, making participants listening and allows you to change your mind along the way. This is in sharp contrast to the political argument, where politicians do not change position but propagandizing parties' ideas. This dynamic process is studied in detail. When a program consists of 8-10 dilemmas, it is possible to look at each participant's ability to get others to change their stance. I use the term meaning-attractor to investigate this and find that it is possible to operationalize the concept and show the difference in team participants to convince. Furthermore it is explored how participants use each other's information and attitudes to fixate their own position. The other is a resource that can be used positively to create a common product, as the final piece of advice is. A comparison of the argumentation in debate, critical discussion and dilemmaargumentation shows important differences and similarities. Finally, it is shown that the dynamics of the dilemma-argumentation is best analyzed in a simpler model than Toulmin's. The warrant is an idle wheel.

\section{Om artikkelforfatteren:}

Ib Ulbæk er lektor ved Institut for Nordiske Studier og Sprogvidenskab ved Københavns Universitet. 


\section{Dilemma-argumentation i radioprogrammet Mads og monopolet $^{1}$}

Der er flere gode grunde til at bruge det i Danmark populære radioprogram, Mads og Monopolet (M\&M), ${ }^{2}$ til en argumentationsanalyse, der vil følge dynamikken i interaktionen. Det er baseret på dilemmaer, der er et godt udgangspunkt for argumentanalyse. Desuden er rådgiverne "almindelig kendte”, de har ikke selv noget på spil i forhold til rådgivningen, fx i modsætning til politikere i en politisk debat. I det følgende vil jeg forsøge at vise, på hvilken måde argumentationen udvikler sig i de forskellige talerunder, som værten etablerer. Det vises i detaljer, hvordan rådgiverne i programmet skifter holdning ved at lade sig påvirke af de andres argumenter. Desuden introduceres begrebet meningsattraktor (en, der trækker de andres holdning sin vej) til at vise forskellen i rådgivernes evne til at flytte holdninger. Endvidere vises det, at selv om holdningerne ligger i strid med hinanden, så er der også en konstruktiv relation mellem dem, som er med til at udvikle en nuanceret forståelse af problemstillingen. Der er en fremadskridende informationsforøgelse, der fungerer som ressource for den beslutning, hver deltager må gøre for at fastlægge sin holdning til det præsenterede dilemma. Dilemmaargumentationen analyseres i forhold til debat og kritisk diskussion som argumentationsplatforme. Endelig vises det, at argumentationens dynamik kan analyseres i deltagernes vurdering af hinandens belæg.

${ }^{1}$ En varm tak til Kate Moelsby for kommentarer og korrektur.

2 De enkelte udsendelser identificeres således: M\&M 51, 14, hvilket betyder Mads og Monopolet uge 51, 2014. Det er netudgaven, som findes på programmets hjemmeside, der bruges, når der citeres, da den nemmere at navigere på og tidsfæste ud fra. Podcastudgaven bruger jeg til gennemlytning, da musikken er skåret fra. 


\section{"Velkommen til programmet"}

Mads og Monopolet har eksisteret som spørge- eller rådgivningsprogram siden 2002 på radiokanalen $\mathrm{P}_{3}$ i Danmarks Radio. 3 Det baserer sig på, at lyttere skriver om deres problemer i dilemma-form til programmet, som udvælger og researcher på et udvalg af dem.

”Det handler om livets spørgsmål $i$ alle størrelser, når Mads \& Monopolet hver lørdag fra kl. 9-12 går i nærkontakt med lytterne” (Præsentation på P3s hjemmeside for Mads og Monopolet). 4

I studiet er studieværten Mads Steffensen og tre kendisser ("holdet”). De kan være skuespillere, musikere, stand up'ere, politikere, erhvervsmænd og kvinder, designere m. fl.5 Lørdag d. 29. november 2014 (M\&M 48, 14) var det komiker/stand up'er Simon Jul, politiker og forfatter Suzanne Bjerrehus og musikeren Wafande (Pierre Jolivel Zahor). Programmet har et fast hold af kendisser, som bruges efter en slags rotationsprincip. Desuden hentes nye kendisser ind med faste mellemrum, fx den unge musiker, Christopher (M\&M 39, 14). Der spilles musik mellem de forskellige spørgsmål, og programmet har en fast musikstump, der fungerer som kending (Peaches in regalia af Frank Zappa, fra albummet Hot Rats (1969)). Programmet har i gennemsnit 600.00o - 800.0oo lyttere, og der er tilknyttet en Facebookside med 217.981 venner (der "synes godt om" programmet), der kommenterer programmet

3 Programmet er per 9. januar 2016 flyttet til P4.

4 http://www.dr.dk/p3/mads-monopolet/

5 I en wikipedia-artikel om Mads og Monopolet er opregnet 44 nuværende og tidligere medlemmer: http://da.wikipedia.org/wiki/Mads og Monopolet 
undervejs og kan deltage i afstemning om udvalgte dilemmaer. Disse afstemninger præsenteres for holdet, efter de selv har givet råd.

Programmet er opbygget ret skematisk. Der indledes med, at værten gennemgår et dilemma fra gangen før med lydklip med de enkelte deltageres input til dilemmaet. Der følges op, gerne i form af spørgerens feedback. Derefter præsenteres holdet (og med særlig fokus, hvis der er en ny deltager), og de udspørges enkeltvis om, hvad der er sket siden sidst eller i den forgangne uge. Der er en afslappet stemning mellem de deltagende. Endelig begynder så selve udsendelsen (vi kan være cirka 20 minutter henne). Efter et antal dilemmaer (ni dilemmaer i M\&M 48, 14) opsummerer værten og opfordrer panelet til at finde det bedste dilemma, som belønnes med en t-shirt (der har en særlig aura, er et helligt objekt - omtales med stor hengivenhed).

Ud over den genkendelige skematik er der også de faste formler, som værten betjener sig af. Nævnt er "Velkommen til programmet”, men også: "I er det bedste hold" (sagt til alle holdene uanset sammensætning, smiger og ironi i ét), "de har ingen aktier i det" og "Det bliver et aldeles fremragende program."6

\section{Argumentationen i Mads og Monopolet versus den politiske debat}

I en politisk debat handler det ikke om at overbevise hinanden om noget, men om at fremføre sin politik mest effektivt, herunder at undergrave andre partiers standpunkter. Selv om der er interessante temaer også inden for den politiske debat, så er der ikke nogen dynamisk udvikling i standpunkterne. De forbliver statiske i debatten. Det er ikke det samme som at sige, at debatten

${ }^{6}$ Det er så indøvet, at i live-udsendelserne kan Mads Steffensen få publikum til at fremsige formlen, fx uge 51, 2014.

I. Ulbæk

$6 / 51$

Sakprosa.no 
ikke er demokratisk frugtbar. Det synspunkt forfægtes af Charlotte Jørgensen (Jørgensen 1995). Selv om debatten tit udarter til eristisk krig, så er debat ikke per definition et skænderi men bundet til de normer, som gælder den særlige kommunikationsform, der fx er i en tv-debat. Debattens natur er bundet til at virke persuasivt i forhold til en tredjepart, det lyttende publikum. Debatten er trialogisk med Jørgensens ord (op. cit. 26).

I M\&M er der tale om dynamisk argumentation;7 der er en drift hen imod at blive enige om at give et enigt råd til spørgeren. Der skiftes (nogen gange) standpunkt undervejs fra deltagernes side. Hvordan og hvorfor undersøges $i$ det følgende. På mange måder svarer formen til den kritiske diskussion, som både analyseres og omfavnes af de hollandske argumentationsteoretikere, Eemeren og Grootendorst, i deres pragmadialektiske argumentationsteori (jf. Eemeren og Grootendorst 2004, men se også Jørgensen op. cit.). Den kritiske diskussion er dialogisk, argumentet er rettet mod diskussionens modpart, lytteren spiller en rolle, men er ikke den, som skal overbevises. Og her skal modtageren rationelt tage stilling til om modpartens argument er bedre end sit eget. Her kunne man sige, at det spiller en rolle, at deltagerne på holdet, ikke som politikere, skal fremføre deres partis politik i en given sag. Dette analyseres i detaljer senere (se afsnittet Tre argumentationsplatforme: debat, kritisk diskussion og dilemmaargumentation).

\section{Dilemma}

Et dilemma består i, at en person har et problem, som tilsyneladende har to løsninger. De to løsninger er gensidigt udelukkende og lige (lidt) attraktive. Udgangspunktet for dilemma-teorien er, at begge valg er negative, at vælge

\footnotetext{
7 Emmertsen 2014 har en tilsvarende dynamisk indfaldsvinkel til argumentation, hvor retorik og samtaleanalyse kombineres, men hun analyserer forhør, der som politikerdiskussioner retter sig mod tredjepart: juryen (jf. ligeledes Kjærbeck og Nielsen 2009).
} 
mellem to onder. Men dilemmaer kan generaliseres til også at omfatte positive valg. Et af de mest kendte dilemmaer er fra Det hvide hotel (D. M. Thomas 1982), hvor den kvindelige hovedperson er fanget med sine to børn af nazisterne. De stiller hende over for at vælge hvilket af sine to børn, der skal henrettes. Uanset hvad hun vælger, er der ikke noget godt valg. Ingen af valgene er gode. Eller hvis et barn får muligheden for at vælge mellem to stykker legetøj i Fætter BR og ønsker begge lige højt men kun kan få det ene. Hvad skal man så vælge? Tilvalget af det ene betyder fravalget af det andet, som man lige så gerne vil have. Eller et moralsk dilemma: En mand ser to mennesker drukne, men kan kun redde den ene. Hvis den ene er hans elskede kone, har han så stadig et dilemma, hvis han uden tøven redder hende (Frankfurt, 2004, s.35 ff.)?

Man kan sige, at hvis der er entydigt rigtige eller forkerte valg, så er der ikke tale om dilemmaer, men om to handlealternativer, hvor det ene er rationelt at vælge, det andet ikke.

I M\&M kan det ses, at selv om alle problemer præsenteres i dilemma-form, så er det ikke alle problemer, lytterne kommer med, der er dilemmaer, forstået på den måde, at panelet let, entydigt og i enighed vælger dilemmaets ene horn. ${ }^{8}$ Men det er bestemt ikke sådan hele tiden, som vi skal se.

Dilemmaer med flere valg end to kaldes trilemmaer, tetralemma eller bare polylemma. Disse udvidede dilemmaer eksisterer ofte i M\&M enten præsenteret af spørgeren selv, eller ved at panelet finder andre løsninger ved

\footnotetext{
${ }^{8}$ Dilemmaer har denne tyremetaforik i den filosofiske tradition, hvor man kan spiddes på enten det ene eller det andet horn. Jeg bruger også en grenmetafor: Dilemmaet grener sig ud. Når der er tale om forgreninger ud over dilemmaet, trilemmaer etc, så er grenmetaforen mere adækvat end tyremetaforen.
} 
siden af det oprindelige dilemma (eller polylemma). Omvendt kan et polylemma også reduceres til et dilemma. 9

\section{Metode}

Som sagt er formålet med denne analyse at undersøge argumentationens dynamik i forhold til et præsenteret dilemma. Og dynamik vil her sige, at der er en bevægelse i holdninger på holdet gennem den tid, som værten sætter af til at diskutere dilemmaet igennem. Da dilemmaet er nyt, skal deltagerne selv beslutte sig for, hvilken holdning de har til det, og hvilket råd denne holdning skal munde ud i, og de skal afstemme deres holdning og råd med de andre på holdet (under eventuel indflydelse af værtens rolle som djævelens advokat). Selv om tilrettelæggerne tilstræber at finde de dilemmaer frem, som vil betyde uenighed på holdet, så er det ikke altid tilfældet. ${ }^{10}$ Hvis et dilemma præsenteres, og holdet er enige i rådet uden debat, så er der ikke nogen dynamik. Men hvis en holddeltager ikke i første omgang kan beslutte sig for, hvad vedkommende tænker, så spiller værten ofte bolden videre og vender tilbage senere, hvor vedkommende så har tænkt og besluttet sig på baggrund af de andres udspil (som han eller hun kan være enig eller uenig i). Dynamik forekommer også, hvis en person ændrer holdning på baggrund af de andres fremførte holdning; det kan både betyde at vedkommende nærmer eller fjerner sig fra de andres holdninger. Så når jeg har villet analysere

\footnotetext{
${ }_{9}^{9}$ Strengt taget kan man operere med et monolemma, nemlig til at udtrykke den reduktion, der sker, når panelet enigt, let og utvetydigt udpeger den ene løsning som værende eneste mulige valg. I det følgende vælger jeg at bruge begrebet.

10 En tak til danskstuderende Tobias Mathiassen, der har været i praktik på M\&M, og har fortalt om redaktionsarbejdet bag kulisserne.
} 
dynamikken i argumentationen, så har jeg fundet eksempler frem af det righoldige materiale, hvor sådanne holdningsskift forekommer.

Jeg søger at belyse argumentationen ved at citere rimelig fyldigt fra udsendelserne. Udskriftformatet følger hverken Dansk Standard 1 eller 2 (Gregersen 1992) eller CA-konventionerne (Femø og Nielsen 2005). Analysen er koncentreret om den indholdsmæssige dynamik og ikke samtaledynamikken, derfor har jeg valgt at lave en udskrift, der er tilstræbt skriftsproglig for at øge klarheden. Der er dog ikke ændret i formuleringerne, men pauser, selvafbrydelser, tøvelyde etc. er ikke medtaget. Overlap indsættes i parenteser, hvor det med initialer fremgår, hvem der afbryder. Afbrydende overlap markeres med parentes med tre punktummer: (...).

\section{Dilemmaanalyse}

Som sagt er der tale om dilemmaer indsendt (eller fremført) af lytterne. Det betyder, at værten spiller en indledende rolle som oplæser af dilemmaet. Når dilemmaet er oplæst, har værten ordstyrerrollen: Han vælger førstetaler og den efterfølgende rækkefølge. Han har også rollen som djævlens advokat, dvs. han er den, som rejser tvivl om paneldeltagernes valg. Det sker i direkte konfrontation med deltageren, mens denne ræsonnerer, eller efter valget er truffet. Det kan også ske i opsamlingen af holdets svar. Som ordstyrer er det også Mads Steffensens rolle at bestemme, hvor mange ture, holdet får. Som oftest er det sådan, at alle tre spiller ud, dvs. kommer med deres første overvejelser over løsningen af dilemmaet. Hvis der er enighed, kan værten så være djævlens advokat over for det svar, for så at sige, at drive en kile ind i enigheden og se om der skulle være nogen, som skifter mening (det gøres med stor præcision og elegance, Mads Steffensen har pt. 13 års erfaring).

Hvis der er uenighed, så får holdet mulighed for at spille op mod hinanden i en anden runde. Og her kan der ske holdningsskift. Der kunne godt være en 
underliggende trang til enighed. Men der kan også være, at en af deltagerne er en meningsattraktor (en, der trækker de andres holdning sin vej): at vedkommende har en så stor ethos, at dennes synspunkt påvirker de andres. Omvendt, så er der mange gange, hvor uenigheden forbliver intakt, også med meningsattraktorer i panelet, og det bliver så de(t) råd, værten meddeler. Det er også hans rolle: At samle sammen. Desuden har han interviewerrollen, når den udvalgte ringes op, eller en fra publikum præsenterer sit dilemma live.

Holdets medlemmer har også bestemte roller og funktioner helt overordnet. De skal lytte til og forstå dilemmaet som præsenteret enten af værten eller den lytter, der er igennem. De skal forholde sig til dilemmaet med henblik på at give råd, dvs. de skal bruge deres viden, erfaring, intuition og klogskab til at fremføre rådet bakket op af grunde til, at rådet er godt. Desuden skal de forholde sig til de andres råd, de andres afvisning af (eller opbakning til) eget råd eller værtens indspil. Endelig skal de monitorere hele processen med henblik på at udforme det endelige råd, også selv om det oftest formuleres af værten til lytteren.

Meningsattraktor er et begreb, jeg har dannet inspireret af begrebet som brugt i den matematiske teori for dynamiske systemer (Gleick 1989). Hvis et dynamisk system har en attraktor, så vil systemet over tid tendere mod at bevæge sig i den retning, hvor attraktoren befinder sig, som stedet, hvor systemet er stabilt. Simplest kan man tænke sig en kugle som spinder rundt i en skål. På et tidspunkt vil kuglen have tabt så meget energi, at den lægger sig til hvile i bunden af skålen, som derfor udgør systemets attraktor. På tilsvarende måde kan rådslagningen bevæge sig ad forskellige baner for at lægge sig til hvile i råd, som stammer fra personen, der fungerer som meningsattraktor. Jeg skal understrege, at begrebet meningsattraktor udelukkende er metaforisk set i relation til teorien for dynamiske systemer. Andre sprogforskere har også brugt begreber fra dynamiske systemer i 
metaforisk betydning, men i mere forpligtet og udvidet forstand (Se Gibbs og Cameron 2008, Larsen-Freeman og Cameron 2008).

\section{Første case: Gaven}

Det første dilemma stammer fra M\&M 45, 14. Holdet er tv-vært Peter Falktoft (gæst, forkortet PF), politiker Morten Messerschmidt (gæst, MM) og skuespiller Christiane Schaumburg-Müller (fast holddeltager, CS-M). Det handler om en maler, som har fået babyudstyr hos nogle kunder. Da han stopper i sit firma, ønsker kunderne gaven tilbage. Hans dilemma er, om han skal beholde gaven eller levere den tilbage.

Mads Steffensen læser dilemmaet op. Det er i mit referat således: Michael er maler og maler for kunder i et hus på Frederiksberg. Arbejdet har stået på i 6 mdr. inden han kommer ind i billedet. Efter at have arbejdet på projektet i 3 mdr. bliver han tilbudt babyudstyr. Han og kæresten venter barn, så de tager i mod gaven og opmagasinerer hos hans svigerfar. Han får så tilbudt job i andet firma, afleverer nøglen og siger tak for gaven. Han modtager så en sms et stykke tid efter, hvor ejerinden vil have tingene tilbage, nu hvor han ikke er ansat længere. Michael er i tvivl om, hvorvidt han skal beholde tingene eller aflevere dem tilbage. Monopolets afgørelse vil blive hans beslutning.

Værten udpeger nu gæsten Peter Falktoft som næstetaler ("Ja, hvad tænker du, Peter?” op. cit. 47:24). Denne påpeger, at modsat hvad man skulle tro, så er han konfliktsky og vil gøre alt for at undgå konflikter. Derfor er rådet fra ham, at Michael skal give gaven tilbage, men at det er småligt af giverne.

Her ser vi værtens rolle som udfordrer, djævlens advokat:

PF: Jeg er et meget konfliktsky menneske. Jeg ville skynde mig at aflevere de ting tilbage. Jeg kan ikke have så noget hængende 
$\operatorname{over}(. .$.

MS: Du ville ikke bryde dig om. Jamen, du har jo fået tingene (PF: Jeg ved det), har har jo ikke gjort noget galt (PF: Jeg ved det) (op. cit., 47:40).

Mads Steffensen begynder sin taletur med at reformulere eller konkludere på PFs indlæg men afbryder og stiller sig antagonistisk an: Michael har ret til gaven. Men PF fastholder:

PF: Tro det eller ej, uden for æterens sendetid der kryber jeg langs væggene for at undgå en konflikt. Jeg synes sådan nogle ting, hvad enten det er folk man kender eller ikke kender så godt, gode venner eller sågar familie, de har altså bare med at ende $i$ hårdknude (op. cit. 47:56).

MS fastholder og udfordrer igen:

MS: Også selv om du ikke kender, de kender jo ikke hinanden. Det er jo ikke familie eller venner. Det er jo nogen, han har arbejdet for. PF: Så går der fem år, så står han med det nye firma i det nye hjem. Altså tingene har det med at bide i halen.

MS: OK OK (op. cit. 48:13).

Først her bryder MS så af, og derefter gives ordet til Christiane SchaumburgMüller, som lægger ud med at indrømme, at hun også er konfliktsky (Mads Steffensen lægger over til hende med ordene: "Hvad så, Christiane, er du også konfliktsky.” op. cit. 48:29), men har også en retfærdighedssans. Så hun opstiller følgende dilemma: Den konfliktsky side af hende vil give tingene tilbage, den retfærdighedskrævende side siger, at Michael skal beholde dem. 
Dette skaber så et intermezzo. Værten påpeger, at tingene har en værdi af $10.000 \mathrm{kr}$, hvilket făr CS-M til at bemærke, at det ikke er værdien, der er afgørende. MM bryder så ind og spørger om det er brugt- eller nyværdien. MS siger, at det er den værdi, eksperter har oplyst. MM bemærker, at brugtværdien vil være langt lavere - og værten samtykker. Det er dog ikke blevet klart, om de 10.00o kr var nyværdien eller brugtværdien.

CS-M ender med at få formuleret dilemmaet, men ikke at give noget råd. Muligvis fordi hun ikke har taget stilling, eller muligvis fordi værten giver ordet videre til Morten Messerschmidt ("Jeg vender tilbage til dig (CS-M: Ja, ja, ja...). Morten, du rystede på hovedet, da jeg læste det her op. Jeg ved ikke hvorfor." op.cit. 50:10).

Morten Messerschmidt opregner to præmisser og drager sin konklusion: 1) gaver er ensidige og uden modkrav; 2) Hvis der er modkrav, så skal det fremgå før givningen. Konklusion: Det er en gave, derfor skal den ikke leveres tilbage. Det vil sige, at han forudsætter, at der ikke er formuleret modkrav. Dette passer med værtens indledende oplæsning af Michaels dilemma. MM fortsætter med at sige, at gaven er givet for allerede udført arbejde og ikke for fremtidigt arbejde, ellers skulle det være fremgået af kontrakten. Værten har allerede på dette tidspunkt bemærket, at der ikke eksisterer nogen kontrakt, nemlig under formuleringen af præmis 2). MM udtaler den regel for giver, at man må stå ved sin gave. Siger så følgende:

MM: Det er ynkeligt at modtage (sic, IU) en sådan sms, og jeg ville skrive tilbage, at det kan overhovedet ikke komme på tale. De kan kontakte hans advokat.

MS: Vil du skrive det?

MM: Ja, det vil jeg i høj grad. Han kan også kontakte mig, så skal jeg gerne formulere brevet. 
MS: (Latter)

(M\&M 45, 14, 50:40)

MM fortsætter i samme tankerække og afslutter derefter med en analogi: Tænk, hvis man skulle give julegaverne tilbage, blot fordi giveren var blevet utilfreds med modtageren.

Hermed er første runde slut. Resultatet frem til nu er, at Peter Falktoft mener, at Michael skal give gaverne tilbage, for ikke at have konflikter og dårlig smag i munden. Christiane Schaumburg-Müller formulerer et dilemma mellem ønsket om retfærdighed og ønsket om at undgå konflikt, men når måske ikke at tage stilling. Morten Messerschmidt formulerer meget detaljeret, hvorfor gaven ikke skal returneres: At det er en gave, som der ikke er formuleret restriktioner i forhold til. Værten har i hele forløbet været en aktiv medspiller, ikke de andre på holdet.

CMS indleder næste runde ved selv at tage ordet. Hun fortæller en historie, om at hun dansede for et firma og havde fået tøj og sko fra det. Da hun senere valgte at stoppe, blev tøj og sko krævet tilbage trods det, at det hele var slidt.

CMS: Og hvad gjorde jeg. Jeg leverede det tilbage. Og det burde jeg nok ikke have gjort. (M\&M 45, 2014, 52.20).

Værten giver derefter ordet til PF.

MS: Men Peter, du er jo også enig med Morten i hans ræsonnement, men din konfliktskyhed vinder alligevel over det (M\&M 45, 2014, 52.35).

PF fastholder sit standpunkt, at ret og rimeligt må vige for god karma: Man ikke skal bruge noget, som andre ønsker tilbage. Han anfører også, at han er for stolt til at bruge noget, som andre har krævet. Begge de nye præmisser bunder altså ikke i konfliktskyhed, men er selvstændige og nye grunde til ikke at følge MM. 
MM tager en tur, hvor han tilbageviser PFs karmaargument; at Michael ikke ville have noget dilemma, hvis han havde det dårligt med at bruge gaven, der er krævet tilbage, og føjer yderligere til, at det må være giveren, der har problemet.

Her er så den afgørende vending for CS-M, hvor hun først hører MM tilbagevise PF og derefter håne afsenderen af SMS

MM: Hvis det var sådan, at Michael slet ikke kunne se sine børn sidde i den her Trip Trap-stol, så ville han jo slet ikke have stillet spørgsmålet (PF: nej), fordi så er det jo spørgsmålet om sit selvværd. Her siger han, at det kan han, går jeg ud fra, sagtens leve med. Er han mere formelt forpligtet? Og der er det bare jeg siger, det er da giveren, der må sidde med en dårlig samvittighed overhovedet at ville sende en sådan latterlig SMS (PF: så absolut, så absolut)

MS: Ja, Christiane

CS-M: Jeg, æh, (rømmer sig), hæhæ (MS: hvad kommer der nu) jeg vil bare sige,jeg slutter mig til, at han ikke skal give det tilbage, for det ville jeg selv ønske, at jeg ikke havde gjort. Altså fordi jeg synes også, at man må slå en streg i sandet. Altså: Jeg synes ikke, han skal give det tilbage. (MM: tak) Så håber jeg han er mindre konfliktsky end jeg (MS: ja) (MM, 45, 14 - 54:oo$54: 47) .{ }^{11}$

\footnotetext{
${ }^{11}$ Under t-shirts-uddelingen, hvor hun vil give t-shirten til Michael, siger hun: "Startede med at sige, at du skal give det tilbage og endte med at sige, ved du hvad, du skal beholde det" (M\&M 45, 14, 2t:48). Hun angiver således ikke selv grunden til at skifte standpunkt.
} 
$\mathrm{Nu}$ har alle tre givet deres bidrag i anden runde og Mads Steffensen opsummerer, at Peter Falktoft vil give gaven tilbage og siger om de to andre:

MS: Morten, og i sidste ende Christiane, siger, at Michael skal beholde det her, så det er to mod en, og det var Monopolet, der jo bestemte (PF: Absolut), så vi siger bare tillykke til Michael med at du har fået ... vundet ... en Trip Trap stol, en rejseklapvogn, en løbevogn og en almindelig klapvogn og en liggestol (M\&M, 45, 14, 55:04).

Vi kan nu aftegne vejen, ad hvilken argumentationen forløber. Holdet får præsenteret dilemmaet, beholde eller aflevere gaven, og det får en udspilsrunde, hvor der skal argumenteres for det ene eller det andet horn (eller ingen af delene, fx en overset udvej, ikke gældende her). Resultatet af første runde bliver en for at aflevere, en imod og en uafklaret. Man kan sige, at med tre holddeltagere, så består dilemmaet efter første runde, det er et ægte dilemma, idet holdet ikke har fundet en løsning, netop fordi Christiane Schaumburg-Müller ikke har taget stilling (eller ikke når at tage stilling). Det sker så i anden runde, hvor CMS følger Morten Messerschmidt, mens Peter Falktoft holder fast i sit oprindelige råd. Dermed står dilemmaets ene gren svagere end den anden, dvs. dilemmaet er opløst eller blevet til et monolemma. Og den gren bliver så svaret eller rådet til spørgeren, Michael.

Men hvorfor flytter Christiane Schaumburg-Müller sig fra uafklaret til at træffe et valg? For det første så er muligheden der for, at hun ikke har skiftet mening, men blot ikke nåede at komme frem til sin egen holdning, jf. at værten fratog hende ordet og gav det til Morten Messerschmidt. I første runde fremsiger hun dilemmaet (som et dilemma ml. retfærdighed og konfliktundvigen) på baggrund af PFs forsvar for den gren, som vil give gaven tilbage. Efter MM har fremført argumenter for den anden gren, fortæller CSM sin historie om sportstøjet som parallelt tilfælde til Michaels dilemma. Hendes konklusion var jo, at hun nok ikke burde have givet tøjet tilbage. Så 
muligheden er, at denne konklusion kommer på baggrund af MMs bidrag - og at hendes endelige valg af råd, at følge MM, kan være den samlede vægt af MMs argumentation og hendes egen historie. Hun angiver selv, at det er hendes egen historie, som burde være sluttet anderledes, og derfor anbefaler hun, at Michael beholder gaven. MMs bidrag er dermed uklart.

\section{Hele udsendelsen}

Men er det muligt ved at se på hele udsendelsen at finde ud af, hvem der "flytter stemmer" (for at bruge en vending fra Jørgensen et al., 1994) eller er en meningsattraktor? Jeg vil i det følgende kort gennemgå hvert dilemma fra M\&M 45, 14 for at analysere talerrækkefølgen og se, hvordan dynamikken i tilslutningen til de forskellige holdninger er. ${ }^{12}$

Første dilemma er en lytter, som er direkte igennem. Han skal deltage i en herrefrokost, hvor der er sket det, at den ene deltager har inviteret sin kusine og en veninde med. Det har skabt ond luft mellem mændene og deres kærester. Morten Messerschmidt lægger ud og argumenterer for, at kæresterne skal med. Peter Falktoft kommer efter og argumenterer for samme standpunkt. Christiane Schaumburg-Müller argumenterer for ren mandeaften med mulighed for, at kæresterne dukker op senere. Disse synspunkter fastholdes i det relativt korte forløb efterfølgende. ${ }^{13}$

\footnotetext{
12 Bemærk, at i det følgende er dilemmaerne udelukkende refereret, fordi hensigten her ikke er at dokumentere dynamikken i rådgivningsprocessen, men at undersøge om en eller flere på holdet er meningsattraktor. Referaterne giver en fornemmelse for bredden af dilemmaerne gennem hele udsendelsen.
}

${ }_{13}$ Første dilemma er lagt til afstemning blandt programmets facebook-brugere. $60 \%$ af dem, der stemte går ind for, at kun mændene skal med, 30 \% mener, at de skal fastholde at kusinen skal med, mens kun $9 \%$ er for, at kæresterne skal med. Værten læser disse tal op i slutningen af udsendelsen. 
Andet dilemma er det ovenfor gennemgåede.

Tredje dilemma handler om en kvinde, som skal giftes, men som nu har fået fantasier om en tidligere bolleven. Skal hun mødes med denne ven for at bolle en sidste gang, skal hun forlade sin forlovede, eller skal hun fortælle det til ham?

CS-M afviser, at hun skal mødes med vennen, og opretter selv et nyt trilemma: Gå fra sin forlovede, fortælle ham det eller undertrykke driften. Ender med at råde til at fortælle det, men ønsker at vende tilbage. PF mener heller ikke, at vennen skal besøges, men mener, at hun nok er nødt til at forlade sin forlovede. MM mener, at bollevennen er symbolet for det uforpligtende, men at hun bør bryde med ham, og i stedet se om hun kan få sit forhold til sin forlovede til at fungere. Hun kan nå at stoppe forholdet inden brylluppet. CSM har nu ændret indstilling efter at have filosoferet over begrebet "kolde fødder”. Spørgeren skal give forholdet en chance og bryde kontakten med bollevennen. PF kommer ikke igen med en ny udmelding. MS lader dette være svar til kvinden: To for at give forholdet en chance, og en for at hun må gå.

Ud over at vi nu har set, at CS-M har skiftet position to gange over til enighed med MM, så kan vi også se, at det oprindelige trilemma ikke opfattes sådan af holdet. Ingen mener, at kvinden skal mødes med bollevennen. CS-M vælger i første omgang den ene af grenene, PF den anden, mens MM formulerer et selvstændigt alternativ, som CS-M gennem sit eget ræsonnement også bifalder.

Fjerde dilemma handler om en ung mand, som har sin mor som ven på FB. Hun liker og kommenterer på alt. Kan han bede hende begrænse sig, eller skal hun have lov at fortsætte? 
PF kender det fra sin egen mor men råder til, at morens adfærd accepteres. MM erklærer sig inkompetent, vælger at følge PF. CS-M mener, at han måske kunne tale med hende på en humoristisk måde men er også mest stemt for bare at lade moren fortsætte. Der er med andre ord enighed på holdet. For dem er det et monolemma.

Femte dilemma er en kvinde, som de taler med. Hun præsenterer det dilemma, at hun har et godt øje til en fyr, som hun vil lære at kende. Han er hendes underbo, og det mener hun er problematisk. Skal hun kontakte ham eller lade være?

De er alle tre enige om, at hun skal kontakte ham. Talerrækkefølgen er MM, $\mathrm{PF}$, CS-M. Igen reduceres dilemmaet til et monolemma, som derfor bliver rådet.

Sjette dilemma er en mand i 30'erne, som skriver på vegne af sig selv og sin lidt yngre søster om faren, som har to andre børn med en anden kvinde, som han også er skilt fra. Disse noget yngre børn har fået børneopsparing lavet af faren, mens de ældre halvsøskende intet har fået. Skal de konfrontere ham med hans forskelsbehandling - ikke for at få penge, men for at få ham til at indse sin forskelsbehandling - eller skal de lade være?

MM indleder: Tal med faren af hensyn til børnebørnene. Men kan det betale sig at tale med ham? spørger CS-M. Og PF er enig, samtale er nyttesløs. MS samler ikke op.

Syvende dilemma handler om en ung mand, der går i 3. g. Han har haft andel i en hest men vil nu købe sin egen, men mener, at det er uforeneligt med et godt eksamensresultat. Skal han købe for at forfølge sin drøm eller tage sin eksamen for at få et godt resultat. 
De er alle enige om at afvise dilemmaet: Det er muligt at forene sin hobby med et krævende år på gymnasiet. CS-M fortæller sin historie, om at hun var danser på fuld tid i alle tre gymnasieår. Det handler om arbejdsmoral, og at hobbyen giver glæde og overskud. MM mener, den unge mand skal tage sig sammen, han skal styre sit liv og tage en god eksamen; den kommer i første række. CS-M er enig i, at han skal prioritere sin eksamen, men at begge dele er muligt. PF, som selv rider, mener også, at den unge kan gøre begge dele, og at vi i samfundet er for fokuseret på eksamenskrav og målretning. MM foreslår i to omgange, at han kan få en delehest nu og overtage den senere eller vente med hesten for at få en god eksamen.

Ottende dilemma er om en kvinde på næsten tredive år, som har været i Jehovas Vidner med sin mand. De trådte ud, fik barn og er nu skilt. Hendes forældre er også i JV og vil derfor ikke have noget med hende at gøre, men de henter barnebarnet en gang om måneden. Hun mener, at enten accepterer forældrene hende og barnet, eller også skal de ikke se barnet, men hun vil ikke fratage barnet dets bedsteforældre.

MM mener, at hun skal søge hjælp i de grupper, som er oprettet til at støtte frafaldne fra sekter, men mener også, at familierelationen betyder meget. Han er stærkt kritisk over for hendes forældres handlemåde. PF mener, hun skal bryde kontakten, da det er psykisk terror, hun er udsat for. CS-M foreslår, at forældrene kun kan se barnebarnet sammen med hende. MS sammenfatter, at rådet er at følge CS-Ms model, men PF fastholder, at hun skal bryde med forældrene.

Niende dilemma er fra en ung elektrikerlærling, som er direkte igennem. Han er næsten færdig som elektriker og har mulighed for at få drømmejobbet i Fredericia, men hvis han vil læse videre, så foregår det i København. Han bor i Odsherred. Skal han flytte eller blive? 
MM drager en parallel til sit eget liv, hvor han flyttede til Randers for at forfølge sin drøm om at blive valgt til Folketinget. Så han råder til, at lærlingen flytter til drømmejobbet. PF er enig, at man skal forfølge sin drøm. Og CS-M er også enig. MS rapporterer enigheden og angiver, at det var et nemt dilemma.

Og ja, det er et eksempel på et nemt dilemma på den måde, at holdet er enig fra starten, og at der ikke skal argumenteres særlig dybt for at få beskåret dilemmaets grene, så det ene står tilbage. Her kan man i øvrigt sige, at godt nok kommer MM først, og hvis han er attraktor, så kunne det synes som om, at de andre to følger ham, men det er nok usandsynligt. Det er en almen forestilling, at man skal forfølge sine drømme, og jobbet i Fredericia var angivet som et drømmejob. Og de angiver, at dels behøver han ikke beholde jobbet i al evighed, kan læse videre senere, dvs. flytte, og dels er Fredericia ikke langt fra Sjælland, så familie og venner kan stadig plejes. Så ud over at denne gren bakkes op af idealforestillingen, så er der flere forhold, som gør denne gren mere attraktiv end den alternative gren.

Med niende dilemma er holdets rolle som rådgivere slut, men det har en sidste opgave, nemlig at give Mads og Monopolet-t-shirten til ugens bedste dilemma. Jeg tager det med, for det er ret sigende. Mads giver et kort rids af alle dilemmaerne. PF lægger ud og vælger sjette dilemma med den uretfærdige far. CS-M vælger det andet dilemma, det med maleren og gaverne, eller tredje dilemma, kvinden, som skal giftes men fantaserer om tidligere bolleven. Efter MS har læst kommentar op fra lytter om det tredje dilemma, vælger CS-M det fra og holder på andet dilemma. MM vælger først to: 5. dilemma med kvinden, der ville i kontakt med sin underbo eller 8. dilemma om Jehovas Vidner, men angiver, at han mest hælder til kvinden fra JV.

Det er interessant, at ingen på holdet har samme dilemma, men at 6., 2. og 8. dilemma er i spil. 
MS spørger om nogen vil give sig, eller om han skal træffe et valg. CS-M angiver, at hun overså JV-dilemmaet, fordi det var kompliceret at give råd, men spørger PF, om de kan acceptere det. PF bejaer og MM samler op: "Så har vi en enighed (M\&M 45, 14, 2:50:25, netudgaven ).” Og det gentager MS, hvorefter programmet afsluttes.

Med en lille tabel kan vi få et overblik over deres råd og valg af grene. Jeg kårer en vinder for hvert dilemma: Den, hvis første bud blev fulgt (eller hvis alle er enige efter første runde: den første som bød ind erklæres vinder, se fx 4. dilemma).

\begin{tabular}{|c|c|c|c|c|c|c|c|c|c|c|}
\hline dilemma & 1 & 2 & 3 & 4 & 5 & 6 & 7 & 8 & 9 & $\begin{array}{l}\mathrm{t}- \\
\text { shirt }\end{array}$ \\
\hline 1. taler & MM1 & $\mathrm{PF} 1$ & CM1 & PF1 & MM1 & MM1 & $\mathrm{CMa}$ & MMa & MM1 & $\mathrm{PF} 1$ \\
\hline 2.taler & PF1 & CM1 & PF2 & MM1 & PF1 & $\mathrm{CM} 2$ & MMa & PF1 & PF1 & $\mathrm{CM} 2$ \\
\hline 3. taler & $\mathrm{CMa}$ & MM2 & MMa & CM1 & $\mathrm{CM} 1$ & $\mathrm{PF} 2$ & $\mathrm{PFa}$ & $\mathrm{CMb}$ & CM1 & $\mathrm{MM}_{3}$ \\
\hline Konklusion & $\begin{array}{l}1: 2, \\
\mathrm{a}: 1\end{array}$ & $\begin{array}{l}2: 2 \\
1: 1\end{array}$ & $\begin{array}{l}\text { a:2 } \\
2: 1\end{array}$ & 1:3 & $1: 3$ & $\begin{array}{l}1: 1 \\
2: 2\end{array}$ & $\mathrm{a}: 3$ & $\begin{array}{l}b: 2 \\
1: 1\end{array}$ & $1: 3$ & $3: 3$ \\
\hline "vinder" & MM & MM & $\mathrm{MM}$ & $\mathrm{PF}$ & $\mathrm{MM}$ & $\mathrm{CM}$ & $\mathrm{CM}$ & $\mathrm{CM}$ & MM & $\mathrm{MM}$ \\
\hline
\end{tabular}

Tabell 1

Tabellen skal læses således: Øverste række angiver hvilket dilemma, der er tale om (samt sidste udfordring, at uddele t-shirt). Kolonnerne angiver talerrækkefølgen fra første runde, femte række, hvad rådet blev, her kaldet konklusion og nederste række udpeger "vinderen" - sat i citationstegn, fordi det ikke er en konkurrence om at vinde på at få sit råd med. Hvis vi læser 1. dilemma, så ser vi, at første taler er MM, og han vælger et råd, som vi her kalder 1. PF følger efter og giver samme råd, mens CM-S (her yderligere forkortet til CM) vælger et alternativ til dilemmaet, her kaldet a (hvis der er 
flere alternativer, så andre bogstaver, se dilemma 8). I konklusionen kan vi se at dilemma-gren nummer 1 har to stemmer, mens alternativet kun har 1 . Da MM er først med at udpege gren 1, og den fik flest stemmer, så er MM vinder (sidste kolonne).

En simpel sammentælling viser, at Peter Falktoft vinder 1. runde, Christiane Schaumburg-Müller vinder 3 runder og Morten Messerschmidt vinder de resterende 6 runder. Det er således belæg for at karakterisere MM som meningsattraktor: Hans indlæg kan få de andre til at skifte mening, og han "vinder" i konsekvens heraf - hans råd bliver det, som holdet melder ud til den spørgende. Man kan næsten ${ }^{14}$ også se, at PF ikke ofte skifter mening. Enten er han på "vinderholdet” fra starten, eller også udgør han den ene minoritet. Den, som skifter oftest mening, er CS-M, men selv MM skifter mening. Dette peger på forskellen på diskussionerne her i M\&M og politiske debatter. Her er det både muligt og ønskeligt at skifte standpunkt. Det er det ikke, når man repræsenterer et politisk parti. ${ }^{15}$

14 "Næsten" ligger i, at i tabellen kan man ikke se i dilemma 2, hvem af CS-M eller PF, der skifter mening. Det gør CS-M, som det fremgik af case-gennemgangen. Så derfor holder PF gennemgående fast i sine råd.

${ }_{15}$ Ud fra hypotesen, at erhvervsmanden og filosoffen Morten Albæk er meningsattraktor, har jeg derfor fundet en tilfældig udsendelse, hvor han deltager og har optalt de gange i udsendelsen, hvor han er "vinder" af argumentationen (M\&M 17, 16). Det er en udsendelse, hvor politikeren Pernille Rosenkrantz-Theil og radiovært Simon Jul også deltager. I udsendelsen er der ni dilemmaer og en uddeling af dagens t-shirt, dvs. 10 runder. Her vinder Morten Albæk en runde, Simon Jul tre runder, mens Pernille Rosenkrantz-Theil vinder de resterende, dvs. seks runder. Så Pernille Rosenkrantz-Theil er meningsatraktoren her. 


\section{De andre som ressource: information og beslutningstagen}

Det følgende er en analyse af den grundlæggende ide, at en tanke- og beslutningsproces må have information at arbejde med for at tænke og beslutte, og at andre personer i omgivelserne kan fungere som kilde hertil. At stille et spørgsmål til en anden er at forstå den anden som kilde, og svaret betyder, at den anden lader sig bruge som kilde eller ressource. Men det kan også forstås i udvidet forstand, at alt, hvad de forskellige holddeltagere her bidrager med, kan udnyttes af de andre holddeltagere som ressourcer, uanset om det er tænkt sådan eller ej. Hvis man ikke kun giver et råd men argumenterer for det, så er det en bedre ressource for den anden, end hvis det kun gives som råd. Begrundelsen er en yderligere information, som ens egen begrundelse kan måles op imod. Rådgivningsprocessen i M\&M er som nævnt anderledes end i den politiske debat. Denne ligner mere den strategi, man kan have i fx et spil som Wordfeud, hvor man forsøger at score så mange point med sine ord men samtidig forsøger at undgå, at modstanderen kan benytte ens ord til at få endnu flere points. Uanset hvad så er den valgte oplægning af ord dog en ressource, den er blot søgt minimeret. På den måde er der i situationen ressourcer, som udgør "affordances" (et begreb fra perceptionspsykologen J. J. Gibson, jf. Gibson 1979).

The affordances of the environment are what it offers animals, what it provides or furnishes, for good or ill (Gibson 1977, 68, senere hyppigt benyttet i multimodalitetsteori, i en lidt ændret betydning). Omgivelserne stiller ressourcer til rådighed for den kognitive proces, som ligger under den proces, der foregår fra holdet får præsenteret dilemmaet til det konkrete råd fremsættes.

Jeg bruger et dilemma fra M\&M 48, 14, hvor musikeren Wafande (W), forfatteren Suzanne Bjerrehus (SB) og komikeren Simon Jul (SJ) er holdet. Mads Steffensen (MS) er selvfølgelig værten. En hobby-privatdetektiv, der 
kalder sig Simon, sættes i dilemma, fordi han har påtaget sig en opgave for en kvinde, som mistænker sin mand for utroskab. Han opdager, at det er en, han har spillet fodbold med, og som netop ikke spiller, fordi han bruger tidspunktet til sit sidespring. Da manden er i bekendtskabskredsen, overvejer han følgende trilemma: Lække til manden, at konen har mistanke, eller skal han fortælle, hvad manden laver, eller skal han gøre som firmaet plejer. Der er en uge til, at rapporten skal overdrages til konen.

Så lad os analysere detektiv-dilemmaet.

\section{Anden case: detektiv-dilemma}

Den første ressource til støtte for beslutningen om hvilke råd, der skal eller kan gives, er selvfølgelig værtens oplæsning af dilemmaet. Man kan forestille sig dilemmaet præsenteres nøgent. Vi vil jo nok studse, hvis vi er præsenteret alene for problemet uden at give en kontekst for, at det er opstået. På den anden side, så viser det nøgne dilemma lidt om, hvilke oplysninger, det skal suppleres med, hvis der skal være information nok til at afgøre, hvilket råd man skal give. Det, man i så fald gør, er på en vis måde at arbejde sig baglæns frem til en brugbar kontekst. ${ }^{16}$

Hvad har holdet brug for at vide for at kunne tage stilling til detektivdilemmaet? Skal Simon (fingeret navn) lække til manden, at konen har mistanke, eller skal han fortælle, hvad manden laver, eller skal han gøre som firmaet plejer? Rent teknisk skal de nok først og fremmest have identificeret

\footnotetext{
${ }^{16}$ I en ikke-udgivet artikel, Tekster læses forlæns, men forstås baglæns, lavede jeg en baglæsning af en lille kort avisnotits. Dvs. jeg begyndte med sidste sætning og spurgte: Hvilken information må denne sætning bero på for at give mening. Og det fortsatte jeg med så godt jeg kunne, så jeg så at sige rekonstruerede den oprindelige tekst ved at se den som kontekstgiver for den næste sætning, når man læser den normalt.
} 
nogle diskursreferenter: Hvem er Simon, konen, manden og firmaet. Dernæst hvilken relation er der mellem dem, og hvori består mistanken, mistanken om hvad. Når vi er kommet så langt, så ved holdet, at Simon er ejer af et detektivfirma, at han er bestilt til at undersøge, om manden til konen er hende utro. Men hvorfor det er et dilemma, vil vi eller holdet ikke forstå, før vi og de får at vide, at han opdagede, at han kendte manden til konen, da han påtog sig opgaven.

Her er hele historien fortalt af MS:

Nu skal I høre, en lytter, der kalder sig Simon, har skrevet til os: Hej, Mads og Monopolet. En lang historie kort. Jeg har et lille firma, der tager opgaver fra kvinder, der er i tvivl om, om deres mand holder sig på måtten, altså om de er utro. Nu har min største bekymring indhentet mig. Vi har fået - og taget - en opgave fra en kvinde, hvis mand jeg dyrker sport med hver uge, eller det vil sige, det gjorde jeg. Selv om han siger til sin kone, at han stadig spiller, så ved jeg, at det ikke er tilfældet. Hun har altså bedt os undersøge, om han opholder sig et andet sted, som hun mistænker. Jeg ved, at hun har ret, fordi han stoppede med at komme til træning for flere måneder siden. Det er jo verdens nemmeste sag at regne ud, at noget er galt, men da det er tæt på, kan jeg godt føle, at jeg er med til at ødelægge et ægteskab. I plejer at sige, at man ikke skal blande sig, men her er det svært at komme uden om, da det er vores arbejde, og vi bliver betalt for at finde sandheden. Skal jeg fortælle ham en hvid løgn og fortælle ham, at jeg har hørt, at hans kone har fattet mistanke, og han nok skal starte til bold igen, eller skal jeg bare fortælle hende, hvad han render og laver, eller skal jeg tage sagen, som jeg ville gøre, hvis det var en hvilken som helst anden kunde? Jeg håber, I kan hjælpe mig, for hun afventer vores rapport i løbet af næste uge. Venlig hilsen Simon. (M\&M 48, 14, 1:01-1:03, netudgaven).

Straks efter dette præsenterer værten bonus-info (som ikke er en del af den oprindelige dilemma-præsentation, men fremkommet, fordi programmet har 
ringet til vedkommende): Spørgeren er ikke venner med vedkommende, men de har fælles venner, og deres børn går i vuggestue sammen. Arbejdets karakter forklares: Bureauet tjekker, om personen er, hvor han angiver at være, og bilen fotograferes på det sted, hvor han i virkeligheden er. Prisen oplyses. Og det fortælles, at Simon har frygtet, at dette skulle opstå. Han har fuldtidsarbejde ved siden af. Han er fyrre år gammel.

Af præsentationen fra spørgeren kan vi rent tekstlingvistisk se, at vi får de ovennævnte oplysninger på måde, så de leder frem til dilemmaet (trilemma i dette tilfælde). Først præsentation af taleren, Simon, at han ejer et detektivfirma, hvilke opgaver, det påtager sig. Og fra denne baggrundsinformation bygges dilemmaet op: At han kender den mand, som er utro. At konsekvensen kan være, at ægteskabet ødelægges. ${ }^{17}$ Dilemmaet er altså, at han ikke vil ødelægge mandens ægteskab, men at han har påtaget sig en opgave, som sandsynligvis vil gøre det. Og ud fra dette opstiller han tre valgmuligheder (det endelige trilemma - at ingen af valgene er attraktive og ingen indlysende bedre valg end andre).

Man kan sige, at Simons, spørgeren, præsentation giver den nødvendige information, for at dilemmaet kan forstås. Som Ole Togeby $(2003,116)$ udtrykker det, så er baggrundsinformationen (kaldet støtteudsagn) nødvendig, men i sig selv irrelevant, mens budskabsudsagnet er relevant, men uforståelig. Tilsammen er helheden forståelig og relevant.

\footnotetext{
${ }_{17}$ En sidebemærkning: Simons arbejde handler om at undersøge utroskab, så det må vel være indbygget i jobbet, at nogen gange går ægteskabet i stykker pga. detektivernes undersøgelser. "I plejer at sige, at man ikke skal blande sig" er ikke helt korrekt, men politikeren Søren Pind fremfører det hver gang, der er veninder, som ved noget om deres venindes kæreste. Her virker det som en appel om at anbefale ham at droppe sagen (en lidt mærkelig appel al den stund, at han har taget sagen - og som fører SB på vildspor).
} 
Den interne fremadskriden og byggen videre på allerede givet information er styret og planlagt i tekster, og evnen til at håndtere dette afgør, om teksten er klar eller uklar (jf. Ulbæk 2005). Vi anede en vis uklarhed i denne præsentation.

Mads Steffensen giver først ordet til Wafande, som starter med at almengøre problemstillingen: Mange mænd og kvinder er utro og står derfor i fare for at blive afsløret. Han siger så:

W: Hvis han ikke er venner med ham fyren men godt vil beholde et godt forhold, så skal han gå op til ham og sige: ”Du er busted. Mit arbejde ved siden af er det her og det her. Jeg er blevet hyret af din kone. Sådan her hænger det sammen. Hvis du vil ordne det, så må du lige tage den, før jeg gør det”. (M\&M $48,14,1: 04)$

W vælger altså at veje den ene gren af dilemmaet tungere end de andre to, nemlig at sige det til den bekendte, så denne kan tale med sin kone. Det gør han, fordi han lægger vægt på, og eksplicit siger det, at det er af hensyn til relationen til manden.

Hvis vi tænker det oprindelige brev og bonusinfo som informationsressourcer, så kan vi se, at han henter det oprindelige dilemma fra brevet og informationen om relationen mellem Simon og manden fra bonusinfo. Bonusinfo, som tilføjes efter den oprindelige formulering, er altså en vigtig ressource for $\mathrm{W}$.

Den næste talende har i sagens natur ikke kun den oprindelige formulering og bonusinfo som ressource, men også W's ræsonnement, hvor han tillægger bekendtskabet større værdi end blot at udføre arbejdet professionelt. Den næste taler er Suzanne Bjerrehus, og hun forholder sig direkte til Ws råd. Hun overtager turen direkte: 
SB: Ej, det siger du ikke. Hold kæft, hvor jeg ville blive tosset, hvis jeg var hende. Ej,jeg taber helt vejret (W: så skal han sige til hende...) Opføre sig professionelt. Det vil han gerne. Er det professionelt, når du har et firma og får noget at vide, og du så render du hen (MS: Det ved han godt, men de er jo lige pludselig, det kan jo godt være, de ikke er venner, men de har jo en eller anden relation, og de ses, og de er del af samme vennekreds). $S B$ : Der er kun en ting at gøre, og det er at sige, at den opgave kan jeg ikke tage, fordi... (MS: Han har taget den) (M\&M, op. cit., 1t:05).

Her ses for det første, at SB formulerer sig i opposition til W ved at vægte den anden gren i dilemmaet: At være professionel. Og for det andet, at det at sige det til den bekendte er uprofessionelt. Derfor bliver hendes råd, at han ikke skal tage opgaven. Det er en misforståelse qua mailens uklarhed (jf. fodnote 17), som MS og W derefter bringer hende ud af. Det vil sige, at de oplysninger først får hende til at trække rådet tilbage og derefter formulerer et nyt råd baseret på den grundværdi, at udfører man et job, så skal det ske professionelt.

Men inden det sker, så får W lejlighed til at uddybe sit råd: At det ikke handler om at forråde konen ved at hjælpe manden, men at han kan komme rapporten i forkøbet ved selv at lægge kortene på bordet, inden den dukker op. Det angreb, som SB fører mod ham, kan også forstås som ressource til at indse, at den oprindelige formulering var for uklar. Med andre ord kan man se den andens holdninger og begrundelser som hjælp til afklaring af eget synspunkt eller som udgangspunkt for reformuleringer. Til at afklare sit standpunkt får W hjælp fra MS:

W: Han skal jo netop sige til sin kone, at han er utro. Det er det, jeg mener.

SB: Du kan jo ikke være sikker på, at han gør det. 
W: Du kan jo sige til ham, prøv at høre her, du skal sige det her, og hvis du ikke gør det, så gør jeg det på et eller andet tidspunkt, for det er mit arbejde. Han kan ligesom sige til ham, den er der nede ...

MS: Der er en rapport på vej, og den kommer til at sige sandheden, så du kan forberede din kone på det.

$W: J a$, præcis.

MS: Det er det, du siger.

SB: Nåh, du siger ikke, at han skal gå hen og sige det inden. Han skal afsløre ham.

$W:$ Nej, nej, han skal forberede manden på det, holde sit bagland i orden. Det er det, der er hans job (op. cit. 1t:o6).

SB kan have opfattet W's holdning sådan, at Simon ved at fortælle manden det, så også skal snyde konen for oplysningerne om utroskab. W. afklarer derfor, at han mener, at ved at fortælle manden det, så skal denne lægge kortene på bordet, og hvis han ikke gør det, så vil rapporten forelægges konen "på et eller andet tidspunkt". Her ser vi arbejdshukommelsens begrænsninger (Eysenck og Kean 2010): Oplysningen om, at rapporten skal afleveres om en uge er ikke aktiv i hukommelsen, så derfor bliver truslen om rapporten vagere, end den kan blive. På den baggrund kan værtens indgriben forstås: Rapporten er på vej, du er nødt til at fortælle hende om din utroskab. Og det synspunkt erklærer W sig enig i.

Der sker således en afklaring i dialogen, hvor der viser sig en partiel enighed. Og den er kun partiel, hvad der fremgår af de næste samtale-træk, hvor MS spørger SB, om Simon skal give manden et "heads up og sige, at du skal lige vide” (ibid.). SB mener ikke, at han skal blande sig.

W mener som sagt, at det skal fortælles til manden inden. Grunden er hensynet til "baglandet", relationerne mellem de to. Informationen om, at de er bekendte 
ud over fodbold, får han fra bonusinformationen. Men det fremgår intetsteds at det er Simons, spørgerens, ønske. Dette ønske om at holde sig gode venner med baglandet kunne skyldes en forestilling om, at detektiven vil blive afsløret, når konen får rapporten. ${ }^{18}$

Simon Juls rolle som ressource for de to andre er lidt anderledes, idet det viser sig, at han via en kammerat har erfaring med afsløring af utroskab ved hjælp af et detektivbureau.

W: Du har prøvet det her før, Simon. SJ: Nej, men jeg har fandeme siddet sammen med en kammerat, som har været i det, og det var ikke særlig pænt, og det endte ikke særlig godt, men på intet tidspunkt blev den der lorte privatdetektiv rodet ind i det her (op. cit. 1:12).

At W spørger kan være en slutning ud fra det foregående, hvor SJ detaljeret forklarer, hvordan processen er fra dokumentationen foreligger, til der eventuelt forekommer en skilsmisse med retssag.

SJ tager meget kraftigt afstand fra detektiver generelt og mener, at deres handlinger har konsekvenser, værst når der er børn indblandet. Men selv om han angiver den mulighed, at spørgeren kan stoppe sagen og give kvinden sine penge tilbage, så vælger han at følge det råd, som også SB er fortaler for: At handle professionelt, ikke fortælle det til manden, men aflevere rapporten, og så må begivenhederne udspille sig på den baggrund.

\footnotetext{
${ }^{18}$ Endnu en sidebemærkning: Man skal bemærke sig forskellen på Simons ønske om måden at fortælle det til manden og så Wafandes. Simon vil benytte sig af en hvid løgn for ikke at afsløre sig selv, mens Wafande lader Simon afsløre sig som detektiv og ophav til en snarlig rapport.
}

I. Ulbæk 
Desværre bliver det ikke tydeligt, om W skifter standpunkt eller fastholder sin opfattelse, for MS konkluderer hurtigt, efter at SJ og SB samstemmende har erklæret sig for den professionelle gren af dilemmaet, at det er holdets råd til spørgeren. Men det ville være rationelt for W at skifte standpunkt, da SJ's indlæg underminerer begrundelsen for at detektiven skal sladre: Detektivens navn vil med stor sandsynlighed holdes ude, uanset hvilket familiedrama der kommer i den følgende tid.

Her er slutningen:

MS: Han har taget skridtet, og nu skal han gøre arbejdet færdigt, det er det, I siger, og ikke noget med lige at sige til ham dér: Begynd lige til træning igen, for (...)

SB: Altså,jeg tror, det er bedre at holde sig, han har lavet noget møg, så (...)

SJ: Forholde sig professionelt til den jobopgave, du har fäet (...)

SB: Det er jo lavet, og det skal afleveres, og det er synd for hende, men det er måske det, hun gerne (...).

SJ: Det er i hvert fald ikke synd for ham. Det er hans opgave. Jeg synes bare, at han skal få det dér ud af verden, og så, øh.

SB: Så må han tage sparkene bagefter, for han ved jo, hvad det er, han laver.

SJ: Jaja.

MS: OK, Lad os sige, det var øh (...).

SJ: Ja det er synd for hende.

MS: et svar til privatdetektiven, Simon, som havde mailet ind monopolet@dr.dk (musik straks herpå) (M\&M 48, 14, 1t:14).

Som det ses, samler MS op, men det er kun SB og SJ, som støtter op om rådet ud fra, at han må forholde sig professionelt. Dog er der et lille indicium på, at 
W også støtter dette, idet han med et lille ja støtter op om SJ umiddelbart før og laver en joke:

MS: Hvor lander du henne, Simon? Hvad skal han gøre, ham her privatdetektiven, Simon.

SJ: Han skal have noget andet at lave.

MS: Skal han lave den her rapport?

SJ: Ja.

MS: Som en hvilken som helst andet rapport?

SJ: Ja, det skal han, fordi han har valgt det her job.

$W: J a$.

MS: Ja.

W: Han skal købe den næste sæson af CSI Miami og så skal han bare (...).

SJ: (Latter). (op. cit. 1t:13).

En forsigtig tolkning af W er altså, at han qua oplysningerne fra SJ skifter standpunkt udtrykt indirekte via sit ja (som ikke behøver at betyde ja, men blot er lytte-bekræftelse) sammen med vitsen med at foreslå køb af amerikansk krimiserie. Igen: At i jagten på et fælles samlet råd bruger de hinanden som ressource eller affordance til at finde ud af, hvilket ben af dilemmaet der er at foretrække eller er det mindste onde. Og i dette tilfælde: ” Eller skal jeg tage sagen, som jeg ville gøre, hvis det var en hvilken som helst anden kunde?” (Simons mail, jf. ovenfor).

\section{Tre argumentations-platforme: debat, kritisk diskussion og dilemma-argumentation}

I det følgende vil jeg mere nøje se på forskelle og ligheder mellem de tre argumentations-platforme, som jeg har opereret med her: Den politiske debat, 
pragma-dialektikkens kritiske diskussion og dilemma-argumentation, som den udfolder sig i disse rammer.

Hvor både debatten og dilemma-argumentationen er eksisterende mediegenrer, er pragma-dialektikkens kritiske diskussion en normativ ramme, for at diskussionens deltagere kan opnå et rationelt resultat af deres indbyrdes uenighed. Men som jeg opfatter den kritiske diskussion, så kan den både udfolde sig i en videnskabelig diskussion (både "live” ved konferencer og disputatsforsvar og i skriftlige diskussioner i tidsskrifter og monografier) men også i mere dagligdags diskussioner, fx når ægtefæller diskuterer, hvor de skal tage på ferie eller hvilken bil, de ønsker at købe. Det afgørende for at overholde den kritiske diskussions regler (jf. Eemeren og Grootendorst 2004, kap. 6) er, at deltagerne overholder samarbejdsprincippet i Grices forståelse af det (Grice 1989): Sig det, som er påkrævet og fornødent på det sted i diskussionen, I befinder jer. ${ }^{19}$

\section{Deltagere}

I den politiske debat vil deltagerne primært være politikere, men der kan også deltage interessenter i det område, som emnet omhandler (fx socialrådgivere og sociale klienter, hvis emnet er nedskæringer i den sociale forsorg). Antallet af debattører kan være fra to og op, nogen gange til en ret uoverskuelig mængde, som når man i Danmark har afsluttende partilederrunder aftenen før et

\footnotetext{
19 "The model of a critical discussion performs both a heuristic and a critical function in the analysis and evaluation of argumentative discourse and texts. The heuristic function is that of being a guideline for the analysis: The model serves as a guide in the detection and theoretical interpretation of every element in, and aspect of, the discourse or text that is relevant to a critical discussion." (Eemmeren og Grootendorst 2004, 58 f.). Nævnte områder, der kan vurderes efter denne standard er retslige procedurer, videnskabelige afhandlinger og politiske debatter. Fordi hverken politiske debatter eller dilemma-argumentation opfører sig i overensstemmelse med det normative skema fra pragma-dialektikken, giver det mening at kontrastere dem alle.
} 
folketingsvalg. Her deltager samtlige opstillede partiers partiledere. I den kritiske diskussion er der to deltagere, en protagonist, som forsvarer et synspunkt, og en antagonist, som modgår synspunktet:

A speaker or writer advances a standpoint and acts as a protagonist, and a listener or writer expresses doubt with regard to the standpoint and acts as antagonist (Eemeren og Grootendorst 2004, 133).

Den prototypiske kritiske diskussion består derfor af to deltagere, hvor protagonisten hævder et synspunkt, som antagonisten bestrider. ${ }^{20}$ Men deltagerantallet i den kritiske diskussion kan udvides opad afhængig af antallet af mulige indvendinger, der er indbyrdes inkonsistente (og der kan være flere på hvert "hold" som i en videnskabelig debat).

Hvad angår deltagerne i dilemma-argumentationen her, så er de allerede præsenteret ovenfor, så jeg nøjes med at tilføje, at antallet tre har flere fordele rent mediemæssigt. Man vil kunne afslutte rådgivningsprocessen demokratisk ved at lade flertallets råd gælde, hvis uenigheden består. Hvert dilemma har en afmålt tid, der mere eller mindre er bestemt på forhånd gennem ønsket om at få et passende antal dilemmaer belyst (og der skal være plads til musik mellem dilemmaerne, hver time afbrydes programmet af radioavisen).

Ved den politiske debat og i dilemma-argumentationen er der ordstyrer; det gælder ikke på samme måde i den kritiske diskussion. Men funktionen af ordstyreren er forskellig i den politiske debat og hos Mads og Monopolet. I M\&M giver ordstyreren netop ordet videre og fungerer som djævlens advokat, fordi dialogen i høj grad går via Mads Steffensen. I den poliske debat har

\footnotetext{
${ }^{20}$ Eemeren og Grootendorst henter inspiration i Aristoteles dialektik og skolastikkens regelstyrede diskussioner, der dog først og fremmest var øvelser (Eemeren et al. 1996, kap. 2)
} 
ordstyreren tilsvarende ret til at fordele taletiden, men desuden har han pligt til at skille de stridende ad, når de går i verbal infight. Der er ikke i M\&M samme antagonistiske relation mellem deltagerne og derfor heller ikke samme følelsesmæssige engagement, der kan udarte til fjendtlighed. Den politiske debats ordstyrer blander sig ikke i debatten, men præsenterer emne, deltagere og sikrer afviklingen af den.

\section{Deltagerformål}

Formålet er enkelt for den politiske debat, idet politikeren debatterer med det formål at vinde tilslutning til sit synspunkt. Og den tilslutning er selvfølgelig rettet ud af debatten, nemlig til tilhørerne, som jeg ovenfor har refereret Jørgensen for at afdække (Jørgensen, 1995). I den kritiske diskussion er formålet at opløse den uenighed, der er mellem protagonist og antagonist om, hvorvidt synpunktet $p$ er sandt eller ej. For så vidt er det ligegyldigt, om protagonisten hævder $p$ eller $i k k e-p$, for som rationelt individ er bestræbelsen at udnytte samtalespillet til at finde det bedste argument, men det betyder ikke, at deltagerne er interesseløse deltagere i samtalen. Både protagonisten og antagonisten må anstrenge sig for at finde de bedste argumenter for deres standpunkt men skal til slut bøje sig for "det bedste arguments tvangsløse tvang” (Habermas, 1971/2001). I dilemma-argumentationen i M\&M er det anderledes, da holdet skal rådgive ud fra dilemmaet præsenteret for dem, dvs. de enkelte deltagere skal i første omgang vælge hvilke af dilemmaets grene (om nogen), de vil ophøje til deres råd. Først i næste omgang skal valget begrundes, og herfra ligner processen den kritiske diskussion, nemlig at finde det råd, der er bedst underbygget. Også her skal deltagerne samarbejde med hinanden og med lytteren. Holdet kan være uheldigt at vælge et forkert råd, men det ville være uetisk med vilje at give lytteren et dårligt råd.

\section{Argumentationens "retning"}

Også i spørgsmål om hvorhen argumentationen retter sig, er der forskelle mellem de tre platforme. Politikerne argumenterer med og mod hinanden, 
men argumentationen er egentlig rettet mod publikum. Argumenterne fremføres ikke for at overbevise hinanden, men for at overbevise publikum eventuelt med henblik på at modtage deres stemmer, men i det mindste for at få tilslutning til synspunktet. I den kritiske diskussion retter argumentationen sig mod deltagerne, der er ingen tredjepart. I M\&M er der tre faser. Der er første fase, hvor det indledende råd retter sig mod lytteren eller ordstyreren og ikke mod de andre på holdet. Dermed opstår der ofte en slags parallelhenvendelse, hvor de tre deltagere på skift henvender sig ud af rummet til den (fraværende) lytter. Der er anden fase, hvor argumentationen dels retter sig mod de andres synspunkter og dels kan blive tvunget til at rette sig mod studieværtens synspunkter, nemlig når denne optræder som djævelens advokat, udfordrer det valgte synspunkt. Tredje fase, der nogle gange falder for tidsgrænsen, er når studieværten klargør, hvilket råd der så gives. Når det ikke sker, skal lytteren (og medlytterne) selv udlede, om et råd er det vindende. Ordstyreren retter talen mod den spørgende. I det følgende vil disse faser belyses mere konkret for M\&Ms vedkommende - det er den argumentationsplatform, der står i centrum.

\section{Argumentationens faser}

Den politiske debat er typisk opdelt i en indledning, hvor ordstyreren præsenterer debattens emne og deltagerne, og en egentlig diskussionsdel, hvor deltagerne efter tur eller tilkendegivelse tildeles ordet og udtrykker sine synspunkter. Der behøver ikke at være anden opsamling end en annoncering af næste uges program (således i Debatten fra Danmarks Radio, d. 15. januar 2016). ${ }^{21}$

Den kritiske diskussion foregår i fire faser:

${ }^{21}$ https://www.youtube.com/watch?v=BOqZl YoMr4

I. Ulbæk 
Analytically, four stages can be distinguished in the process of resolving a difference of opinion that the participants in an argumentative exchange of views have to pass through to arrive at a resolution of a difference of opinion. These stages - which we call the discussion stages of critical discussion - are the "confrontation" stage, the "opening" stage, the "argumentation" stage, and the "concluding" stage (Eemeren og Grootendorst 2004, 59).

Den konfronterende fase består i at klarlægge, om der er en uenighed; åbningsfasen om denne uenighed også kan behandles argumentativt ud fra et fælles grundlag - begge disse faser udgør en slags forberedende betingelser i Searles forstand (jf. Searle 1969). Den argumenterende fase er ikke overraskende den fase, hvor argumenterne for eller imod $p$ bringes i spil. Hvis den argumenterende fase munder ud i en afgørelse, kan denne gøres eksplicit i den afsluttende fase.

Faserne i Mads og Monopolet er som skitseret ovenfor anderledes. I centrum for udsendelsen står dilemmaerne indsendt af lytterne. Formålet med det forsamlede hold er at give råd på basis heraf. I modsætning til den kritiske diskussion er der ikke en første fase, hvor der afklares, om der er uenighed og dermed grund til at afklare denne uenighed. Efter oplæsningen af dilemmaet gives ordet til den første deltager, som verbaliserer sit råd gennem et eksplicit ræsonnement. De næste to giver tilsvarende råd - og som bemærket ovenfor, så er det råd rettet mod lytteren, men samtalen kan gå mod værten eller forholde sig til de andre, men nogen gange kunne alle råd opfattes som parallelle - dvs. uden et forudgående råd. Det er som om rådene gives simultant og uden hensyn til de andres råd. Hvorfor opstår den oplevelse? Jo, det skyldes, at deltagerne ikke forholder sig til det eller de forudgående råd. Hvis rådgiver 2 giver samme råd som rådgiver 1, så kunne man forvente, at vedkommende hægtede sig på det foregående oplæg med udsagn som ”Ja, jeg 
vil lægge mig i forlængelse af X’s opfattelse...” Eller omvendt, at nr. 2 ville lægge afstand til nr. $1 .^{22}$

I det følgende vil jeg demonstrere faserne konkret ud fra et enkelt dilemma i M\&M 17, 16. Det er udsendelsens sjette dilemma, og holdet består den dag af radiovært Simon Jul, direktør og filosof Morten Albæk samt politiker Pernille Rosenkrantz-Theil. Dilemmaet er indsendt af en kvinde, der kalder sig Louise, som skal holde sin 30 års fødselsdag for mange mennesker. Men hendes far er få måneder forinden blevet varetægtsfængslet for økonomisk kriminalitet. Skal Louise fortælle a) sandheden eller b) finde på en historie om at faren er syg eller er ude at rejse?

Her er de første udmeldinger fra første runde - som sagt, er det parallel udmeldinger fra første til andet taler, mens tredje taler er så uenig med de to første, at hun må stille sig i opposition:

\section{MS: Hvad synes du, Morten Albæk?}

MA: Jeg synes i den grad, hun skal fortælle sandheden. Jeg synes, at hun så fint formulerer det til sidst, at hun ikke er flov over sin far, men at hun forstår ikke hans valg i livet. Og det er sådan set dér, hun skal starte sin fortælling (M\&M 300416, 1:39ff)

\section{(...) (Råd: skal sige det)}

MS: Simon, hvis han bare er ude at rejse. Det jo bare en lille hvid løgn, der kan få hende til at tænke lidt på noget andet og ikke stå til ansvar for alle vennerne.

\footnotetext{
${ }^{22}$ Jeg har lavet en optælling af udsendelsen M\&M 17, 16. Der er 20 mulige parallelhenvendelser og ud af dem er 13 parallelle, mens 7 forholder sig til den eller de foregående taleres bidrag.
} 
SJ: Der er to ting i det her. Nu er hendes far kommet ind at sidde $i$ spjældet for økonomisk kriminalitet. Er den økonomiske kriminalitet noget, der påvirker det lokalsamfund, hun er i. For det kan faktisk godt have en stor betydning for, hvordan man skal administrere sandheden

\section{(...) (Råd: skal sige det)}

PR: Ej, hvor er jeg uenig med jer (SJ: Nå). Nu må I fandme stoppe (MS: Ja, Godt... SJ: Godt, Pernille). Altså, vi har selv valgt vores børn, og det vil sige, at hvis vores børn kommer $i$ spjældet, så har man et vist ansvar til at stå ved det og forklare omgivelserne det. Vi har ikke selv valgt vores forældre... (Råd: Skal ikke sige det).

Her ser vi, at de første to deltagere adresserer Mads Steffensen, som også stiller spørgsmålet, mens PR er selvvælger og vælger at adressere de to andre på holdet.

Efter denne første fase af råd plus begrundelse kommer den egentlige argumenterende fase, hvor deltagerne forholder sig til hinandens argumenter. I dette dilemma kommer konfrontationen direkte efter, at PR har forklaret, hvorfor hun ikke mener, at spørgeren skal fortælle vennerne om faren. ${ }^{23}$

MS: Jah, Morten Albæk, du markerede.

MA: Jo, men det er fordi, at når hun så bliver spurgt til nære venner, og hun svarede, og de så spørger tilbage "Hvor er han så”, skal hun så lyve? Og der har jeg har det principielle

\footnotetext{
23 Faktisk afbryder SJ - lidt usædvanligt for genren - PR undervejs i hendes indlæg, måske provokeret af hendes hæftighed. Der spilles tilbage med samme mønt, så at sige.
} 
standpunkt, at jeg tror ikke på, at du gør noget godt for din egen sjæl og dit eget livsforløb ved at lade de små løgne komme ind $i$ dit sind (PR: Jamen, hvorfor lyve) (M\&M 300416, 1:45).

I analogi med den kritiske diskussion, så viste PRs åbning, at der var en uenighed, som nu forsøges afgjort med henblik på at give et fælles råd som den overordnede præmis. Der er således en lang duel mellem PR og SJ, hvor temaet er, hvilke venner skal vide det, overfor om hun ved at fortie faderens fængsling vil blive offer for rygter. Diskussionen forløber mellem dem uden, at værten griber ind, men han vælger på et tidspunkt at adressere MA for at få ham til at uddybe sin opfattelse, at det er vigtigt, at der ikke er for langt mellem tanke, ord og handling, at man er transparent. Han angribes af PR, for at han heller ikke siger alt til alle. Han gentager sin opfattelse og det samme gør SJ, hvorefter studieværten springer den opsamlende fase over - det vil sige, at det ikke klargøres for spørgeren, hvilket råd, holdet kan give. Men da der ikke ændres holdning blandt deltagerne, så er det den indledende fordeling, der gælder som råd. Så selv om Pernille Rosenkrantz-Theil er meningsattraktor i denne udsendelse (jf. note 14), så lykkes det hende ikke at få en eller begge af de andre til at skifte mening.

Hele analysen af de tre argumentationsplatforme kan sammenfattes i følgende tabell (tabell 2): 


\begin{tabular}{|c|c|c|c|}
\hline & Politisk debat & Kritisk diskussion & $\begin{array}{l}\text { Dilemmaargumentation i } \\
\text { Mads og Monopolet }\end{array}$ \\
\hline Deltagere & Politikere & Hvem som helst & Kendte \\
\hline Antal & $\mathrm{n}=2$ eller flere & $\mathrm{n}=2$ & $\mathrm{n}=3$ \\
\hline Ordstyrer & $\mathrm{Ja}$ & Nej & $\mathrm{Ja}$ \\
\hline Ordstyrerrolle & $\begin{array}{l}\text { "sikre ro", } \\
\text { fordeler af } \\
\text { taletid }\end{array}$ & Ingen & $\begin{array}{l}\text { Djævlens advokat, fordeler } \\
\text { af taletid }\end{array}$ \\
\hline Medie & Radio, tv, møder & Intet & Radio \\
\hline Deltagerformål & $\begin{array}{l}\text { Overbevise } \\
\text { tredjepart: } \\
\text { Vælgerne } \\
\end{array}$ & Løse uenighed & Give råd til lytter \\
\hline $\begin{array}{l}\text { Ændring af } \\
\text { synspunkter }\end{array}$ & $\begin{array}{l}\text { Nej, men } \\
\text { nuancering } \\
\text { mulig }\end{array}$ & $\mathrm{Ja}$ & $\mathrm{Ja}$ \\
\hline Udsagnstype & p vs ikke-p & p vs ikke-p & $(\mathrm{p}->\mathrm{r}, \mathrm{ikke-p}->\mathrm{r})->\mathrm{r}$ \\
\hline Udgangspunkt & Uenighed & Uenighed & Mulige forskelle i opfattelse \\
\hline Hvordan tales & Mod hinanden & Med hinanden & Parallelt og med hinanden \\
\hline $\begin{array}{l}\text { Argumentationens } \\
\text { faser }\end{array}$ & $\begin{array}{l}\text { Indledning, } \\
\text { debat, afslutning }\end{array}$ & $\begin{array}{l}\text { Konfrontation, } \\
\text { åbning, } \\
\text { argumentation, } \\
\text { konklusion }\end{array}$ & $\begin{array}{l}\text { Dilemma-præsentation, } 1 . \\
\text { udspil, 2. diskussion, } \\
\text { opsamling }\end{array}$ \\
\hline
\end{tabular}

Tabell 2

\section{Argumentationsforløbet - en argumentmodel}

Standardmodellen, når man analyserer retorisk argumentation, er Toulmins argumentmodel fra The uses of argument (Toulmin 1959). Som bekendt har den tre obligatoriske komponenter: Påstand, belæg og hjemmel (eng. claim, data og warrant). Det betyder, at når man (herunder studerende, der skal 
tilegne sig modellen) analyserer virkelig argumentation, som sjældent indeholder hjemler, så er man forpligtet på at inkorporere disse i sine modeller af argumentationen (jf. Jørgensen og Onsberg 2008). På denne forfatter virker det som systemtvang og i virkeligheden et levn fra den syllogistiske logik, dvs. fra den præmoderne logik. Men det er samtidig en logik, Toulmin tog afstand fra med dens geometriske og universelle form. ${ }^{24}$

Som bekendt er moderne formel logik en meget friere form end formkravet til syllogistisk logik og til Toulmins argumentmodel. Vi kender fra almindelig dagligdags ræsonnementer (ofte demonstreret i quizprogrammer) "udelukkelsesmetoden". Man stilles over for et alternativ: Enten er påstand $a$ sand, eller også er påstand $b$ sand. Men man ved eller tror, at $a$ er falsk, og derfor slutter man, at påstand $b$ er sand. Dette ræsonnement er logisk gyldigt men har hverken syllogistisk form eller behov for en overordnet hjemmel:

$((a v b) \&-a)->b$

Men jeg påtænker ikke i det følgende at bruge formel logik til at analysere argumentationen i Mads og Monopolet men blot udnytte den struktur i forløbet af diskussionerne, som deltagerne udnytter. Og det vil helt skematisk sige, at en deltager fremsætter et synspunkt og begrunder det, næste deltager fremsætter et andet synspunkt og begrunder det, og det gør tredje deltager så også. Så det essentielle fra Toulmin er en simplere struktur: Påstand og belæg (jf. Ulbæk 2016). Deltagerne rekonstruerer ikke hjemler i deres forholden sig til de andres argumenter, de vurderer ganske simpelt, om de andres belæg er

\footnotetext{
24 Det skal retfærdigvis siges, at med rygdækning (backing) indføres dels en induktiv komponent i modellen (jf. Nielsen 1999), dels et brud med det universelle, idet argumentationen bliver feltafhængig (Toulmin 1959, Eemeren og Grotendorst 1996, 135 ff.).
} 
bedre end deres egne. Og det er en vurderingssag: Er de andres argumenter bedre end mine, og vil jeg i så fald skifte mening?25

Lytterdilemmaet er her, hvorvidt en kvinde skal tage på ferie med sin utro mand (M\&M 300416, 59:00-1:09 i netudgaven). I kort referat lyder dilemmaet således:

En kvinde, Stine, skal med sin mand og barn til Bali. Fire uger inden opdager hun mandens utroskab og bryder med ham. Manden angrer og bryder med elskerinden. Stine lader ham flytte tilbage, men inden affæren har de altså købt de en rejse til Bali. Kvindens dilemma er nu, om hun skal rejse til Bali med eller uden sin mand. ${ }^{26}$

SJ: $\quad$ Råd: Tag manden med ud at rejse

Belæg: Kan man tilgive halvt, lade manden flytte tilbage, men ikke rejse med?

PR: $\quad$ Råd: De skal ikke nødvendigvis rejse ud sammen.

Belæg: Det er den vildeste livskrise. Kvinden har et princip om ikke at acceptere utroskab, men principper kan ikke bruges til noget, da det handler om følelser. Man skal blive sammen, hvis følelserne og kærligheden er der. Barnet taler også for at de skal blive sammen. Hun er ikke færdig med processen og har brug for

25 Eller andre konstruktive udviklinger: at de andres ræsonnementer bruges som ressource til andre argumenter, jf. diskussionen ovenfor.

${ }^{26}$ Hvis det ikke fremgår eksplicit, at der er holdets indlæg i det følgende i referat og tilpasset formatet "råd-belæg". Det anbefales selv at lytte til dilemmaet i følgende link: http://www.dr.dk/p4/mads-monopolet/mads-monopolet-2016-04-22 
ro. Hvis de rejser, skal de have klare aftaler om muligheden for at være alene.

MA: Råd: Hun skal kun rejse med ham, hvis hun har tilgivet ham.

Belæg: Har hun tilgivet ham? Der er kun gået fire uger, og det virker som om hun kun har tilgivet halvt, så hun har brug for mere tid.

Efter første runde af holdets indlæg ses det, at kun SJ har et klart og ubetinget råd, baseret på et "har man først sagt A, så må man også sige B"-råd. Både PR og MA giver betingede råd, der begge handler om, hvor langt Stine er i krisen. MA trækker på SJs belæg om den halve tilgivelse men bruger det til at sige, at den halve tilgivelse kan skyldes, at hun ikke er færdig med at bearbejde krisen.

I anden runde fastholder SJ sit råd om at tage af sted men betinger det nu med "klare aftaler", dvs. har lyttet og modificeret sit råd ud fra PRs indlæg, der således også fungerer som ressource. PR gentager sit råd om klare aftaler, mens MA inddrager sønnen på 9 år og spørger retorisk om denne skal være øjenvidne til et "parterapeutisk eksperiment".

Rådslagningen slutter med en række hurtige ordvekslinger, hvor SJ gentager sit belæg, at de bor sammen, mens MA igen henviser til SJs bemærkning om den halve tilgivelse, og at hun derfor stadig er i tvivl. PR strammer sit råd fra det betingede ud fra aftalerne om, at kvinden skal tage af sted alene med barnet. MS samler ikke sammen, så der gives ikke et entydigt råd fra holdet, idet SJ går ind for at parret rejser sammen, PR er imod, og MAs råd er betinget af, hvor langt Stine er i tilgivelsesprocessen.

Det ses af min analyse, at den simple opdeling i råd (påstand i

Toulminmodellen) og belæg giver et godt overblik over, på hvilken måde rådet 
understøttes, og vi ser videre, at hjemlen er overflødig argumentatorisk set, da ingen af deltagerne efterspørger hjemler men udmærket kan argumentere imod de andre på basis alene ud fra råd og belæg. Når SJ som belæg for sit råd angiver belægget, at de bor sammen, og de andre to alligevel vælger at komme med andre råd, så opfattes hans belæg ikke som tilstrækkelig for at følge ham og give tilslutning til det samme råd. Selv om det ikke siges eksplicit, så betyder denne fremdskriden, at SJs belæg ikke ses som tilstrækkeligt tvingende til, at de dels skulle begynde med at være enige, og dels heller ikke senere skifter holdning trods det, at SJ gentager det som grund til at følge hans råd. Det ses også, at både PR og MA har mere komplekse belæg, der dog ikke får SJ til at skifte holdning, kun at modificere den, så han anbefaler udrejse betinget af klare aftaler. PR på sin side skifter holdning fra at kunne være enig med SJ om, at parret rejser ud med klare aftaler, til at hun ender med at råde kvinden til at rejse uden manden. MAs råd er betinget og af en sådan karakter, at kvinden for at følge ham skal træffe en afgørelse om, hvor langt hun er i tilgivelsesprocessen. ${ }^{27}$ Reglen for at skifte mening er den simple, at hvis modpartens belæg ses som bedre end mit eget, så skifter jeg mening ellers ikke. Her sker der ikke dramatiske skift, men alligevel modificeringer, som beror på den dynamik, der er i argumentationsforløbet.

\section{Konklusion}

Artiklen havde til formål at vise, hvordan argumentation omkring dilemmaer kan udspille sig i en kontekst, hvor det er tilladt at skifte standpunkt, nemlig i Mads og Monopolet. Dermed er det også muligt at se i detaljer, hvilke grunde, andre fremfører, som kan få en til at skifte standpunkt. De gennemgåede cases

\footnotetext{
${ }^{27}$ Hvis jeg skal evaluere på argumentationsforløbet, så gør PR og MA ret i ikke at følge SJs råd. Han er for ensidig i sine belæg og udbygger ikke argumentationen, efter han har hørt de andres grunde til at tænke anderledes. Der er mere at sige om den sag, end SJ er villig til at tænke. Han mener, at han har et "knock down-argument", det mener de andre ikke.
} 
belyste dette. Og samtidig var det muligt gennem en samlet analyse af et helt program at se om nogen af deltagerne var bedre til at overbevise de andre om deres valg af råd, om de tiltrak de andres mening, var meningsattraktorer. Artiklens anden del valgte en anden synsvinkel på argumentationen, nemlig at se på forholdet mellem information og valgte råd, hvor information blev anskuet som ressource for at beslutte sig for et valg. Så selv om der er antagonismer qua forskellige opfattelser, så kan modsatrettede synspunkter også ses som en ressource for at danne sin egen mening. Noget sådan kan man ikke få øje på, hvis man kun kender argumentation fra den politiske sammenhæng, fordi holdningen er skabt på forhånd - og derfor er de andre ikke en ressource i denne forstand. Da beslutningstagen sker over tid, vokser mængden af ressourcer og dermed troen på, at det råd, der gives til slut også er mere velbegrundet end de første udspil. Der er flere perspektiver, som bakker op omkring det. Analysen af de tre argumentplatforme viser, at der er vigtige forskelle mellem dem alle, og at der er ligheder og forskelle på tværs af de udanalyserede parametre. Endelig viser jeg, at vi kan (og bør) klare os med en enklere argumentmodel end den toulminske, når vi analyserer argumentationsdynamikken i M\&M. Hjemlen spiller ingen rolle i rådslagningen og virker derfor overflødig. Fokus er på belægget både blandt deltagerne og i analysen af argumentationen.

\section{Litteratur}

Eemeren, Franz H. van og Rob Grootendorst 2004. A systematic theory of argumentation: The pragma-dialectical approach. Cambridge: Cambridge University Press.

Eemeren, Frans H. van, Rob Grootendorst og Francisca Snoeck Henkemans 1996. Fundamentals of argumentation theory. A handbook of historical 
backgrounds and contemporary developments. Mahwah, New Jersey: Lawrence Erlbaum Associates, Publishers.

Emmertsen, Sofie 2014. Retorisk samtale og argumentationsanalyse. I Marie Lund og Hanne Roer (red.). Retorikkens aktualitet. Grundbog i retorisk kritik. København: Hans Reitzels Forlag. 219-238.

Eysenck, Michael W. og Mark Keane 2010. Cognitive psychology: a students handbook. London: Psychology Press.

Frankfurt, Harry G. 2004. The reasons of love. Princeton: Princeton University Press.

Gibbs, Raymond W., og Lynne Cameron 2008. The social-cognitive dynamics of metaphor performance. Cognitive Systems Research, 9(1), 64-75.

Gibson, James J. 1977. The theory of affordances. I Robert Shaw og John Bransford (red.). Perceiving, acting, and knowing. Towards an ecological psychology. Hillsdale, New Jersey: Lawrence Erlbaum Associates, Publishers. S. 67-82.

Gibson, James J. 1979. The ecological approach to visual perception. Bosten: Houghton Mifflin.

Gleick, James 1989. Kaos: en ny videnskabs tilbliven. København: Munksgaard.

Gregersen, Kirsten 1995. Dansk standard for udskrifter og registrering af talesprog, 2. udgave. Tillæg A til Snak 5. Årgang.

Grice, Paul 1989. Studies in the way of words. Cambridge, Massachusetts: Harvard University Press. 
Jørgensen, Charlotte 1995. Debattens væsen og uvæsen. Retorik studier, nr $10,3-43$.

Jørgensen, Charlotte; Christian Kock og Lone Rørbech 1994. Retorik der flytter stemmer. København. Gyldendal.

Jørgensen, Charlotte og Merete Onsberg 2008. Praktisk argumentation. København: Nyt Teknisk Forlag.

Kjærbeck, Susanne og Niels Møller Nielsen 2009. Det gode naboskab? En undersøgelse af etnometodologisk samtaleanalyse og pragmatisk argumentationsanalyse som tilgange til sprog i praksis. Rita Therkelsen og Eva Skafte Jensen (red.) Dramatikken i grammatikken. Udgiver: Institut for Kultur og Identitet. Roskilde Universitet. 233-266.

Larsen-Freeman Diane og Lynne Cameron. 2008. Complex Systems and Applied Linguistics. Oxford: Oxford University Press.

Nielsen, Mie Femø og Søren Beck Nielsen 2005. Samtaleanalyse. København: Samfundslitteratur.

Searle, John R. 1969. Speech acts. An essay in the philosophy of language. Cambridge: Cambridge University Press.

Thomas, D. M. 1982. Det hvide hotel. Århus: Centrum

Togeby, Ole. 2003. Fungerer denne sætning? Aarhus: Aarhus Universitetsforlag.

Ulbæk, Ib 2005. Sproglig tekstanalyse. Introduktion til pragmatisk tekstlingvistik. København: Academica. 
2016 @ Sakprosa

Bind 8, Nr. 2

Ulbæk, Ib 2016. En argumentmodel uden hjemler. Manus.

Ulbæk, Ib u.å. Tekster læses forlæns, men forstås baglæns. Upubliceret manus.

I. Ulbæk 